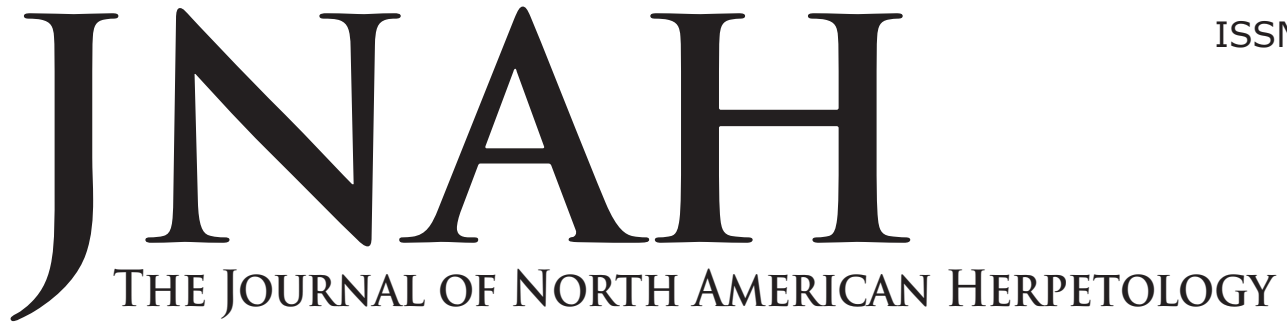

ISSN 2333-0694

Volume 2020, Number 1

23 March 2020

journals.ku.edu/jnah

\title{
SHORT TERM MICROBIAL COLONIZATION OF REPTILE ROADKILL
}

\author{
ZEB. C. HULL ${ }^{1}$, AND SHEM D. UNGER ${ }^{1,2}$ \\ ${ }^{1}$ Department of Biology, Wingate University, Wingate, NC 28174, \\ ${ }^{2}$ Author for Correspondence: s.unger@wingate.edu
}

\begin{abstract}
Little is known about how microbes such as bacteria and fungi in the environment temporally colonize common roadkill reptile carcasses (turtles and snakes). We opportunistically collected and deployed a variety of reptile carcasses often found deceased near roads, including an Eastern Ratsnake (Pantherophis alleghaniensis), an Eastern Box Turtle (Terrapene carolina), and a Snapping Turtle (Chelydra serpentina). We sampled bacteria communities of these carcasses daily for five consecutive days. We enumerated the number of colony-forming units (CFUs) and characterized microbial distinct colonies using morphology and identification of dominant colonies using 16S rRNA sequencing across carcasses. Several ecologically relevant bacterial phyla were successfully identified colonizing and dominating carcasses differentially, including members of Actinobacteria, Firmicutes, and Proteobacteria. We observed higher bacterial colonization (CFUs) for both terrestrial and aquatic turtles, $T$. carolina and $C$. serpentina, compared to $P$. alleghaniensis. This study provides baseline data on the temporal microbiology of deceased reptiles found on roads in the piedmont of North Carolina.
\end{abstract}

Key Words: Anthropogenic Mortality, Microbiology, Scavenging, Bacteria, Turtle, Snake

\section{INTRODUCTION}

Each year many reptiles are observed deceased on roads (Dodd et al., 1989), often in urban areas when they are either basking or crossing roads and fall victim to vehicular encounters (Smith and Dodd, 2003; Degregorio et al., 2011). This includes representatives from Squamata and Testudines (Quintero-Angel et al., 2012; Gibbs and Shriver, 2002). Once these host organisms die, their own native microflora combine with other soil microbes present in the environment which begin to differentially colonize a decomposing carcass (Howard et al., 2010). Among microorganisms, both fungi and bacteria are known to colonize different surfaces of both living and decomposing animals (carcasses) albeit, at different stages (Carter et al., 2007). While all types of reptile carcasses are scavenged by a variety of vertebrates and invertebrates, often within hours after death (Abernathy et al., 2017), very little is known regarding dominant microbial communities which sequentially colonize reptile roadkill (Cooper, 2012), especially within the first few days of mortality.

The microorganisms of terrestrial and aquatic habitats are ubiquitous and abundant, comprising a diverse array of microbial communities in the environment. These varied bacterial and fungal microbes have many different roles on living reptiles, with some being beneficial (Bouchard and Bjorndal, 2005), some detrimental (Jho et al., 2011), and others likely omnipresent animal, soil, and environmental microbes. Bacterial and fungal communities in the soil where mortalities occur are incredibly rich and extremely diverse (Dunbar et al., 2002). They thrive and change in composition temporally, depending on myriad of factors including soil composition, nutrient presence, location, $\mathrm{pH}$, temperature, and humidity (Fierer and Jackson, 2006). Cadaver studies in mammals have found vast differences in microbial communities between initial deployment (day 0 ) and day 5 , with early communities dominated by the phylum Proteobacteria (largely aerobic bacteria) and later stages dominated by the phylum Firmicutes or anaerobic bacteria (Pechal et al., 2014). However, there is a dearth of information on dominant microbial communities of herpetofauna.

In this study we used standard microbiological techniques (enumerating cultured bacteria on selective media and characterization of colony morphology) and $16 \mathrm{~S}$ rRNA sequencing (for identification confirmation) to examine the diversity of microbial flora present on decaying reptile carcasses over a period of four days. Our experiment simulated a turtle or snake being run over near a road with the carcass coming to rest in a nearby forested roadside area. We report on the relative abundance and short-term bacterial growth as a component of the microbial ecology of a reptile carcass. 


\section{METHODS}

Field Sampling - A total of three reptile carcasses were deployed in a forest area on Wingate University, Wingate, North Carolina: a Snapping Turtle (Chelydra serpentina) on 27 March 2018, and on 10 April 2018, an Eastern Ratsnake (Pantherophis alleghaniensis, and an Eastern Box Turtle (Terrapene carolina). Carcasses were obtained in coordination with local state North Carolina Wildlife Resources Commission biologists and kept frozen until deployed. Areas of the mixed Oak-Hickory hardwood forest floor, comprised of a combination of Willow Oak (Quercus phellos), Shagbark Hickory (Carya ovata), Sweetgum (Liquidambar styraciflua), and Shortleaf Pine (Pinus echinata), were cleared of leaves and debris prior to deployment. Carcasses were carefully placed in covered forested areas near a paved highway ( $\sim 5$ meters) to simulate natural road mortality but include surrounding roadside soil microbes. We sampled for microbes using Pur-Wraps ${ }^{\circledR}$ sterile collection swabs (Puritan Medical, Maine). Gloves and foot covers were worn when sampling to prevent contamination or introduction of additional microorganisms. All carcasses were swabbed externally across all surfaces (shell, head, body, and cloaca) immediately upon initial deployment for a total of ten seconds. Each carcass was swabbed twice using this procedure, and a randomly selected swab was used for microbial plating on media. Swabs selected were placed in sterile $10 \mathrm{ml}$ collection tubes. This procedure was repeated for 4 more days (with Day 0 = first deployment day).

Laboratory Methodology - Swabs were taken each day to the laboratory and agar plates were made in triplicate for each carcass and for two different agar media, Brain Heart Infusion (BHI) and Potato-Dextrose Agar (PDA) following standard gel preparation guidelines (Cappuccino and Welsh, 2017). To select for bacteria and limit overall fungal growth, we added $1 \mathrm{ml}$ of cycloheximide per liter to the BHI mix. A total of 450 plates were used at 5 different ten-fold serial dilutions $\left(10^{\wedge} 0,10^{\wedge} 1,10^{\wedge} 2,10^{\wedge} 3\right.$, $10^{\wedge} 4$ ), for 5 days (Day $0,1,2,3$, and 4), across carcasses (Eastern Ratsnake, Eastern Box Turtle, and Snapping Turtle), for both media (PDA and BHI) in triplicate. Samples were serially diluted in $100 \mu$ increments, up to $10^{\wedge} 4$ based on initial dilution ratios following standard protocols (Cappuccino and Welsh, 2017) and injected on to agar gels (plates) in $100 \mu$ increments and spread using a sterilized metal rod. The plates were then incubated at $20^{\circ} \mathrm{C}$ for approximately 48 hours to ensure proper growth of mesophilic bacteria (Lagier et al., 2015).

Following incubation, we assessed microbial growth by counting individual colonies on plate lids (Cappuccino and Welsh, 2017). We enumerated the amount of CFUs (colony-forming units) per $\mathrm{ml}$ for all dilution plates exhibiting 30 to 300 colonies. The average number of colony-forming units was determined across media and averages were compiled for both media. We further characterized colony characteristics and morphology (shape, color, and other defining characteristics) for each plate. Distinct colonies which we observed to be dominant were individually grown using four-way streaking methods to ensure purity (Seeley and Vandemark, 1962; Cappucino and Welsh, 2017). Of these, we selected a subset of 11 dominant colonies for identification via 16S rRNA sequencing. A Gram stain was performed on these same colonies to aid in identification (Sanders and Miller, 2010). We then ran a standard colony PCR (Lane, 1991) and gel electrophoresis to confirm PCR product. Colony
PCR was performed in Bio Rad thermocyclers and consisted of $50 \mu$ reactions: 25 GoTaq $^{\circledR}$ G2 master mix, $2 \mu \mathrm{l}$ forward primer, $2 \mu$ l reverse primer, and $21 \mu$ of water using 16SrRNA gene universal ReadyMade ${ }^{\mathrm{TM}}$ Primers (Integrated DNA Technologies). The thermal profile consisted of 10 minutes at $94^{\circ} \mathrm{C}$, then $30 \mathrm{cycles}$ of $94^{\circ} \mathrm{C}$ for 30 seconds, $58^{\circ} \mathrm{C}$ for 30 seconds, and $72^{\circ} \mathrm{C}$ for 1 minute and 50 seconds, ending with $72^{\circ} \mathrm{C}$ for 10 minutes. Standard $16 \mathrm{~S}$ rRNA sequencing was performed by Eton Bioscience (www.etonbio.com). Gene sequences were subject to Basic Local Alignment Search Tool or BLAST (https:// blast.ncbi.nlm.nih.gov/Blast.cgi) to determine probable identity of isolates with $99 \%$ sequence identity.

\section{RESULTS}

Across carcass types, days sampled, and serially diluted plates, $67.3 \%$ of $C$. serpentina plates cultured bacterial colonies, whereas $80 \%$ of $T$. carolina and $48.7 \%$ of $P$. alleghaniensis plates successfully cultured bacterial and fungal colonies (Figure 1). Across all plates, we detected ten distinct fungal types, representing only $\sim 12$ non-yeast fungal colonies, confirmed via microscopic examination using a compound light microscope at $40 \mathrm{X}$ magnification, therefore we report mainly on bacterial

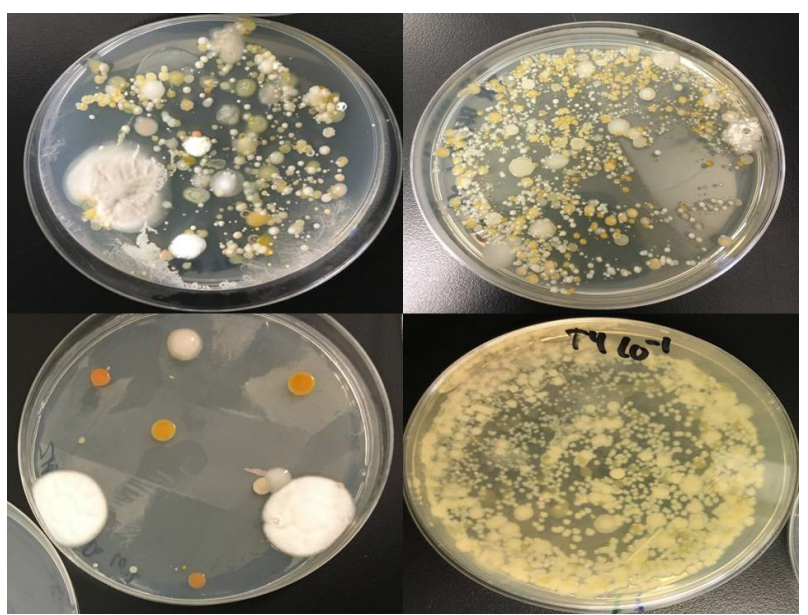

Figure 1. Representative bacterial agar plates showing distinct colony morphology and numbers in cultured media of $T$. carolina: Day 0 (top left), C. serpentina: Day 0 (top right), P. alleghaniensis Day 0 (bottom left), and T. carolina: Day 4 (bottom right). Note higher number of CFUs for both turtles.

colonies. Nine of the 11 dominant isolates, which were comprised largely of bacteria, were positively identified and confirmed according to $16 \mathrm{~S}$ rRNA sequencing, Gram staining, and colony morphology (Table 1). Bacteria cultures for number of colonies varied across media and dilution factor, with both BHI and PDA media exhibiting bacterial growth at most dilutions $\left(10^{\wedge} 0,10^{\wedge} 1,10^{\wedge} 2\right.$, $10^{\wedge} 3$ ) with minimal growth observed for $10^{\wedge 4}$ dilution. We observed a greater number of CFU's in both turtle carcasses across the experiment compared to the snake carcass (Figure 2). Overall CFUs increased each day the carcass was in the field, with higher CFU values observed on day 2 for $T$. carolina. Bacteria that colonized carcasses included representatives from phyla Actinobacteria, Firmicutes, and Proteobacteria, with representative genera Staphylococcus, Gordonia, Bacillus, Serratia, Streptomyces, Chryseobacterium, and Pantoea (Figure 3). 
Table 1. 16S rRNA probable identity of isolates with host carcass, day sampled, dilution, gram staining, and basic morphology of microbial communities in our study. 16S rRNA identification of highest probable identification of genus based on BLAST alignment.

\begin{tabular}{|c|c|c|c|c|c|c|}
\hline Isolate & $\begin{array}{l}16 \text { S rRNA } \\
\text { Identification }\end{array}$ & Host Carcass & $\begin{array}{l}\text { Day } \\
\text { Sampled }\end{array}$ & Dilution & $\begin{array}{l}\text { Gram } \\
(+/-)\end{array}$ & $\begin{array}{c}\text { Colony Morphology, } \\
\text { Shape, and } \\
\text { Arrangement }\end{array}$ \\
\hline A & Staphylococcus & Ratsnake & 3 & $10^{\wedge} 0$ & + & $\begin{array}{l}\text { Dull, yellow, circular, } \\
\text { entire: Staphylococci }\end{array}$ \\
\hline B & Gordonia & Ratsnake & 2 & $10^{\wedge} 2$ & + & $\begin{array}{c}\text { Tan, irregular, raised: } \\
\text { Bacillus }\end{array}$ \\
\hline $\mathrm{C}$ & Unknown & Box Turtle & 4 & $10^{\wedge} 2$ & - & $\begin{array}{l}\text { Circular, raised, } \\
\text { convex, Bacillus }\end{array}$ \\
\hline $\mathrm{D}$ & Bacillus & Box Turtle & 2 & $10^{\wedge} 2$ & + & $\begin{array}{l}\text { Irregular, rough, } \\
\text { raised: Streptobacillus }\end{array}$ \\
\hline$E$ & Serratia & Box Turtle & 2 & $10^{\wedge} 1$ & - & $\begin{array}{l}\text { Circular, off-white, } \\
\text { entire: Bacillus }\end{array}$ \\
\hline $\mathrm{F}$ & Bacillus & Snapping Turtle & 0 & $10^{\wedge} 0$ & + & $\begin{array}{l}\text { Raised, volcano- } \\
\text { shaped: } \\
\text { Streptobacillus }\end{array}$ \\
\hline G & Streptomyces & Box Turtle & 0 & $10^{\wedge} 3$ & + & $\begin{array}{l}\text { Circular, entire, } \\
\text { raised, powdery: } \\
\text { Filamentous }\end{array}$ \\
\hline $\mathrm{H}$ & Chryseobacterium & Snapping Turtle & 0 & $10^{\wedge} 2$ & - & $\begin{array}{l}\text { Bright, orange, } \\
\text { iridescent, flat, } \\
\text { circular: Bacillus }\end{array}$ \\
\hline I & Pantoea & Box Turtle & 3 & $10^{\wedge} 3$ & + & $\begin{array}{l}\text { Dull, yellow, flat, } \\
\text { oval: Bacillus }\end{array}$ \\
\hline J & Unknown & Ratsnake & 4 & $10^{\wedge} 0$ & - & $\begin{array}{c}\text { White, flat, circular: } \\
\text { Yeast }\end{array}$ \\
\hline $\mathrm{K}$ & Pantoea & Box Turtle & 2 & $10^{\wedge} 2$ & + & $\begin{array}{c}\text { Dull, yellow, circular: } \\
\text { Bacillus }\end{array}$ \\
\hline
\end{tabular}

\section{DISCUSSION}

While the study of reptile carcass microbiology is limited, much of the focus in bacterial communities in reptiles has focused on detection and prevalence of the Salmonella bacteria (McCoy and Seidler, 1973) in turtles, which we did not detect. Out of the eleven isolates selected for sequencing, nine of them were able to be identified with some degree of certainty using $16 \mathrm{~S}$ rRNA sequencing. The majority of plates and isolates included several

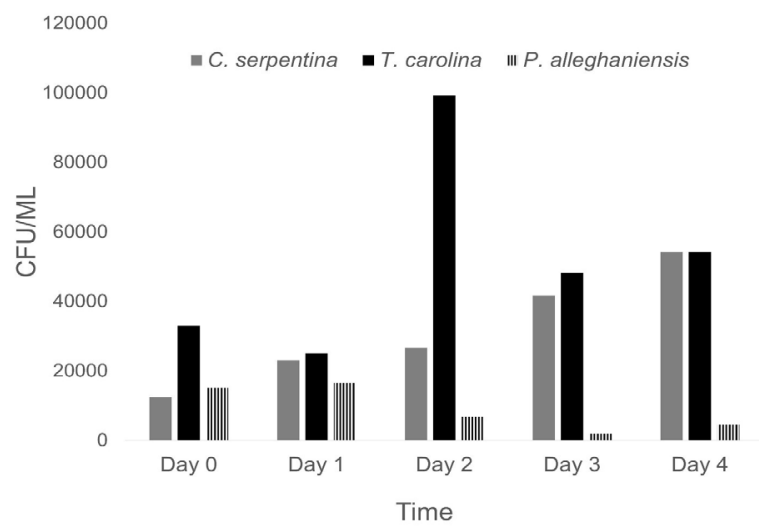

Figure 2. Bacterial growth measured by colony-forming units (CFUs) per milliliter observed across carcasses for Day 0 (carcass deployment) to Day 4. Note both turtle carcasses (Chelydra serpentina and Terrapene carolina) with higher CFU values than the Eastern Ratsnake (Pantherophis alleghaniensis). types of environmental bacteria, including Gordonia, and the non-pathogenic Bacillus. In this study, we also observed Serratia, a soil bacterium which can be pathogenic in some nematodes and insects (Kwak et al., 2015), an opportunistic pathogen in humans (Hejazi and Falkiner, 1997), and previously detected in the Red-eared Slider, Trachemys scripta elegans (McCoy and Seidler, 1973) and Green Sea Turtles, Chelonia mydas (Santoro et al., 2006). Another isolate we identified, Chryseobacterium,

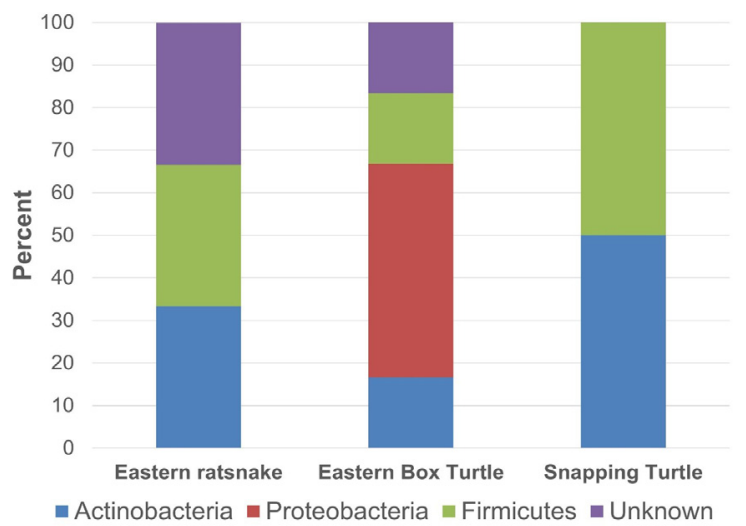

Figure 3. Relative abundances (\%) of Bacteria phyla identified across carcass type (Eastern Ratsnake, P. alleghaniensis, Eastern Box Turtle, T. carolina, and Snapping Turtle, C. serpentina), with Actinobacteria and Firmicutes present in all reptile carcasses. 
is a pathogenic and prolific soil bacterium which may be a health risk for immune-compromised individuals (Bhalla et al., 2018). Little is known regarding another isolate, Pantoea, which is a diverse group of bacteria both ubiquitous in the soil environment and with some varieties potentially pathogenic to humans, plants, or both (Deletoile et al., 2018). Staphylococcus has previously been documented in the microbiota of reptiles (Walther et al., 2008).

Based on our findings, it appears that of the bacteria observed and identified, almost all of them are common in the soil or the environment. It is unknown to what extent these bacteria affected decomposition rates and if they are common on live reptiles or simply common soil bacteria which colonized carcasses. We successfully observed several dominant types of microbial communities across carcasses. However, given our limited sample size $(N=3)$ and time frame (Day 0 to Day 4$)$, it is likely we preferentially observed the most ubiquitous bacteria present on carcasses at one time. Alternatively, major groups of bacteria may have outcompeted other bacteria groups present but in smaller overall colonies, resulting in the specific groups we observed being the most prominent species present during sampling or successfully grown on a variety of media plates. Decomposition of animal carcasses, and thus colonization by both insects and bacteria, is strongly affected by temperature (Howard et al., 2010) and season (Pechal et al., 2013). Future studies could focus on increased sampling post mortality and in a variety of environmental and temporal conditions (i.e. spring vs. summer, or at varying humidity and temperatures).

The higher counts noted for both turtle species compared to the snake may be due to increased bacterial colonization of overall greater surface area (shell) or alternatively a more diverse surface morphology (plastron, head, and limbs) for bacteria to colonize than the snake carcass, mainly elongate body and keeled scales of the snake carcass. Further research and sampling could examine specific anatomical regions across carcass types as well as internal versus external bacteria as decomposition progresses in reptiles. Moreover, the microorganisms inherent in soil communities should also be studied to compare bacteria already present at time of death to differentiate the role of environmental versus bacteria present or common on living reptiles. Lastly, the role of various insect scavengers we occasionally observed visiting the decomposing carcasses should be further examined, as each may harbor their own unique microbial communities, and potentially transfer them to decomposing reptile carcasses.

In conclusion, there remains much work to be done regarding microbial communities of both wild reptiles and amphibians, including the diverse microflora which colonize herpetofauna which die from either natural causes, disease, or anthropogenic roadkill mortality. The microbiome of herpetofauna remains a vastly understudied area of research, particularly as it relates to decomposition and the ecology of visiting invertebrate and vertebrate scavengers, which may further alter carcass microbial communities. Therefore, we recommend increased attention with further experimental variables considered in future research and possibly incorporation of emerging technologies, such as next-generation sequencing approaches in the study of the "living dead" of reptile and amphibian carcass microbiology.
Acknowledgements - We thank the Wingate University Biology Department for funding and Mark Rollins for assistance in the field. North Carolina Division of Wildlife provided guidance on carcass collection and permitting. We also thank members of the Wingate Biology Department for help in microbiology methods, study design, and project development.

\section{LITERATURE CITED}

Abernathy, E.F., K.L. Turner, J.C. Beasley, and O.E. Rhodes Jr. 2017. Scavenging along an ecological interface: utilization of amphibian and reptile carcasses around isolated wetlands. Ecosphere. 8:1-12.

Bhalla, G.S., S. Gupta, M.S. Sarao, and D. Kalra. 2018. Chryseobacterium indologenes: Case report of an emerging pathogen. Journal of Marine Medical Society. 20:70-72.

Bouchard, S.S. and K.A. Bjorndal. 2005. Microbial Fermentation in Juvenile and Adult Pond Slider Turtles, Trachemys scripta. Journal of Herpetology. 39:321324.

Cappuccino, J.G. and C. Welsh. 2017. Microbiology: A Laboratory Manual. $11^{\text {th }}$ ed. Pearson Education Press, UK.

Carter, D.O., D. Yellowlees, and M. Tibbett. 2007. Cadaver decomposition in terrestrial ecosystems. Naturwissenschaften. 94:12-24.

Cooper, J.E. 2012. The estimation of post-mortem interval (MNI) in reptiles and amphibians: current knowledge and needs. The Herpetological Journal. 22:9196.

Degregorio, B.A., T.E. Hancock, D.J. Kurz, and S. Yue. 2011. How quickly are road-killed snakes scavenged? Implications for underestimates of road mortality. Journal of the North American Academy of Science. 127:184-188.

Deletoile, A., D. Decre, S. Courant, V. Passet, J. Audo, P. Grimont, G. Arlet, and S. Brisse. 2018. Phylogeny and identification of Pantoea species and typing of Pantoea agglomerans strains by multilocus gene sequencing. Journal of Clinical Microbiology. 47:300-310.

Dodd, C.K., Jr., K.M. Enge, and J.N. Stuart. 1989. Reptiles on Highways in North-Central Alabama, USA. Journal of Herpetology. 23:197-200.

Dunbar, J., S.M. Barns, L.O. Ticknor, and C.R. Kuske. 2002. Empirical and Theoretical Bacterial Diversity in Four Arizona Soils. Applied Environmental Microbiolology. 68:3035-3045.

Fierer, N. and R.B. Jackson. 2006. The diversity and biogeography of soil bacterial communities. Proceedings of the National Academy of Sciences. 103:626-631.

Gibbs, J.P. and W.G. Shriver. 2002. Estimating the effects of road mortality on turtle populations. Conservation Biology. 16:1647-1652.

Hejazi, A. and F. R. Falkiner. 1997. Serratia marcescens. Journal of Medical Microbiology. 46:903-912.

Howard, G.T., B.D. Duos, and E.J. Watson-Horzelski. 2010. Characterization of the soil microbial community associated with the decomposition of a swine carcass. International Biodeterioration and Biodegredation. 64:300-304.

Jho, Y.S., D.H. Park, J.H. Lee, S. Cha, and J.S. Han. 2011. Identification of bacteria from the oral cavity and cloaca of snakes imported from Vietnam. Laboratory Animal Research. 27:213-217.

Kwak, Y., A.R. Khan, \& J. Shin. 2015. Genome sequence of Serratia nematodiphila DSM 21420T, a symbiotic 
bacterium from entomopathogenic nematode. Journal of Biotechnology. 193:1-2.

Lagier, J., S. Edouard, I. Pagnier, O. Mediannikov, M. Drancourt, D. Raoult. 2015. Current and Past Strategies for Bacterial Culture in Clinical Microbiology. Clinical Microbiology Reviews. 28:208-236.

Lane, D. J. 1991. 16S/23S rRNA sequencing. In Stackebrandt, E. and M., Goodfellow (eds.), Nucleic acid techniques in bacterial systematics, John Wiley and Sons, USA.

McCoy, R.H. and R.J. Seidler. 1973. Potential pathogens in the environment: isolation, enumeration, and identification of seven genera of intestinal bacteria associated with small green pet turtles. Applied Microbiology. 25:534-538.

Pechal, J.L, T.L. Crippen, A.M. Tarone, A.J. Lewis, J.K. Tomberlin, and M.E. Benbow. 2013. Microbial community functional change during vertebrate carrion decomposition. PLoS One. 8:e79035.

Pechal, J.L., A.M. Crippen, M.E. Benbow, A.M. Tarone, S. Dowd, and J.K. Tomberlin. 2014. The potential use of bacterial community succession in forensics as described by high throughput metagenomics sequencing. International Journal of Legal Medicine. 128:193-205.

Quintero-Angel, A., D. Osorio-Dominquez, F. Vargas-Salinas, and C. A. Saavedra-Rodriquez. 2012. Roadkill rate of snakes in a disturbed landscape of Central Andes of Columbia. Herpetology Notes. 5:99-105.

Sanders, E.R. and J.H. Miller. 2010. I, Microbiologist A Discovery-Based Course in Microbial Ecology and Molecular Evolution. ASM Press, USA.

Santoro, M., G. Hernandez, M. Caballero, and F. Garcia. 2006. Aerobic bacterial flora of nesting green turtles (Chelonia mydas) from Tortuguero National Park, Costa Rica. Journal of Zoo and Wildlife Medicine. 37:549552.

Seeley, H.W. and P.J. Vandemark. 1962. Microbes in Action: A laboratory manual of microbiology. $1^{\text {st }}$ ed. WH Freeman, USA.

Smith, L.L. and C.K. Dodd, Jr. 2003. Wildlife mortality on US highway 441 across Paynes Prairie, Alachua County, Florida. Florida Scientist. 66:128-140.

Walther, B., L.H. Wieler, A.W. Friedrich, A. Hanssen, B. Kohn, L. Brunnberg, and A. Lubke-Becker. 2008. Methicillin-resistant Staphlylococcus aureus (MRSA) isolated from small and exotic animals at a university hospital during routine microbiological examinations. Veterinary Microbiology. 127:171-178. 